\title{
A REVIEW ON UTILIZATION OF MINE WASTE ON BLACK COTTON SOIL
}

\author{
S.A Kanalli ${ }^{1}$, Sureka Naagesh ${ }^{2}$, Ganesh $\mathbf{K}^{3}$ \\ ${ }^{I}$ Assistant professor, Department of Civil Engineering, SDMCET Dharwad, Karnataka, India \\ ${ }^{2}$ Professor, Department of Civil Engineering, BMSCE Bengaluru, Karnataka, India \\ ${ }^{3}$ Assistant Professor, Department of Civil Engineering, BMSCE Bengaluru, Karnataka, India
}

\begin{abstract}
Mine wastes are one of the chronic waste concerns. The volume of solid waste generated during mining process, is one of the main pollution concern. The presence of high concentration of heavy metals and acid producing mineral phases can endanger the environment if management of these wastes are not addressed properly. Mine wastes have numerous ecological effects viz Air, Land and Water. There is a great difficulty in finding space for the storage of wastes generated in enormous quantity. The review of past studies indicated that 50 to $60 \%$ of mine waste by volume can be used as coarse grained particle and 10 to $15 \%$ by volume as fine aggregate. Despite quite a lot of attempts to diminish the amount of waste, mine waste remains one of world's largest waste streams. Black cotton soil on the other hand is problematic due to the presence of momtmorillonite that imparts high swellshrink potentials. These soils are very hard when dry but loose strength completely when wet. Pavement surface on poor soil subgrade show early distress causing pavement failure. The present study examines the utilization of these wastes as stabilizers for black cotton soil for unpaved road construction.
\end{abstract}

Keywords: Mine Waste, slag aggregate, Solid Waste Materials, Iron Ore slag

\section{INTRODUCTION}

Mining in India meets the mineral requirement of various industries. India is highly potential to produce large quantity of Iron ore, moderate to high quality for domestic use and export. Waste from extractive operation is one among the largest waste streams. It entails materials that must be removed to get admittance to the mineral resource, such as overburden, topsoil and waste rock, as well as tailings left over post extraction of minerals from the ore. The type, amount, and properties of mine waste produced at different mines vary depending on the resource being mined, process technology used, and geology at the mine site. These mining operations produce waste materials which currently has modest or no economic value. [1] The soil and rock which is removed to gain access to buried ore, and the material (water, solids, and gases) left behind after the ore has been processed to remove the valuable commodities, are considered to be waste materials. However mineral content between ore and waste rock can differ depending on market conditions and available extraction technology.

There are numerous cases where material that was once considered waste has become a resource for modern mining operations. [2]. Overburden that includes soil and rock is removed to gain access to the ore deposits at open pit mines. It is usually piled on the surface at mine sites which does not impede further expansion of the mining operation.

These mining operations comprises of removal of overburden to entrée the ore contribute to major problems in storage and reclamation. 2:1 to 5:1 waste to ore ratio is generated depending on local condition. 16 to 20 million tons of ore produce 40 to 50 million tons of waste per year with waste ratio of 3:1 for present condition [1]. To dump the waste mining companies had to acquire private land exterior to the lease area due to exhaustion of the present land. Mining has a number of widespread activities, each of which has potentially-adverse effect on the natural environment, society and cultural heritage. It also affects the health and safety of mine workers, and communities located near the mining operation sites. The requirement of extra land will increase every year unless there is a proper technique for the use of these wastes.

The presence of heavy metals also causes erosion and dust. The impacts can have long lasting socio-economic and environmental effect. It may lead to tremendously difficult consequences and may prove expensive to handle through remedial measures. Management of Wastes from the extractive industries plays a vital role in ensuring the longterm stability of disposal unit and to prevent water and soil pollution that is arising from acid or alkaline drainage and heavy metal leaching.

\subsection{World outlook on Mine Waste Usage}

Mine waste consists of unmodified natural material other than crushing. Overburden and Top soils classified as wastes are used as raw material as additive in building materials and for recuperating extroverted material such as Aluminum.

In recent years countries contributing the production of minerals have come across problems on improved utilization of mine waste of its gathering and lack of suitable storage space. The utilization of mining waste has been done as a 
construction material in road construction, railway, river and dam. It's use has widely increased in 20 years. An example for direct of Mine waste as bulk fill in the Mining Industry, Ruhr has been mentioned in the table below [1].

Table 1.1: Usage of Mine waste as Construction materials

\begin{tabular}{|l|l|}
\hline Construction & $\begin{array}{l}\text { Quantities } \\
\text { (MillionTon) }\end{array}$ \\
\hline Dykes and dams & 2.62 \\
\hline Earth and road construction & 6.61 \\
\hline Filling in sand pit and gravel & 3.0 \\
\hline Mine waste discharge in to rivers & 3.55 \\
\hline Total Usage & 15.78 \\
\hline
\end{tabular}

\subsection{Black Cotton Soil}

The black cotton soil of India covers an area of at least 200,000 sq.miles and ranks as the second most important of our Indian soils. It is the largest proportion of our Indian cotton crop is grown.

Black cotton soils are the most problematic clays due to their strange swell shrink behaviour with abrupt variations in moisture content. Most of the world nation has surface area covered by the Black cotton soil and huge damages caused by them have been reported. It has been investigated that the presence of clay minerals like montomorillonite induces the swell-shrink behavior to these soils. For any country, transport and communication are the major influential factors for the development of countries. Importantly for highly populated countries like India, road transport is the major dependent feature for connectivity and accessibility of different locations. During the process of network development, the road alignment may have to be fixed, though the soils en-route may not be suitable to bear the traffic loads with adequate strength. It has been established that the stability and performance of pavement is reflected by soil sub grade, Pavements constructed on expansive soils are bound to fail resulting in poor performance and increased maintenance cost. Past studies have shown that the stabilization of black cotton soil with lime, flyash, GGBS etc have resulted in to enormous advantages like improvement the soil strength. Reduction in soil volume changes due to moisture and temperature, improved soil workability and durability. It has also brought economy in the cost of road. An attempt can therefore be made to use mine waste for the stabilization of black cotton soil.

Table 2.1: Utilization of Mine waste as construction material and stabilizer with Black Cotton Soil

\begin{tabular}{|c|c|c|c|}
\hline $\begin{array}{l}\text { Alteration } \\
\text { Agent }\end{array}$ & Test Carried & Remarks & References \\
\hline Mine waste & $\begin{array}{l}\text { Particle size } \\
\text { distribution } \\
\text { UCS }\end{array}$ & $\begin{array}{l}50-60 \% \text { of the Mine waste can be used as Coarse aggregate and } \\
10-15 \% \text { by volume as fine aggregate. This material had resulted } \\
\text { in higher UCS value for a concrete mix of } 1: 2: 6 \text { as compared to } \\
\text { the conventional aggregate for the same mix. }\end{array}$ & $\begin{array}{l}\text { Mohan Yellishetty, } \\
\text { et al. } \\
(2008)\end{array}$ \\
\hline $\begin{array}{l}\text { Aggregate }+ \\
\text { Iron ore slag } \\
\text { Aggregates }\end{array}$ & $\begin{array}{l}\text { Life cycle } \\
\text { inventory } \\
\text { assessment }\end{array}$ & $\begin{array}{l}\text { For every } 1 \% \text { replacement of Iron ore slag aggregate, there was } \\
\text { a reduction in 8tonnes of mine waste. }\end{array}$ & $\begin{array}{l}\text { Sathyanarayanan } \\
\text { Rajendran et al. } \\
(2007)\end{array}$ \\
\hline $\begin{array}{l}\text { Aggregate }+ \\
\text { Iron ore slag } \\
\text { Aggregates } \\
\text { (mine } \\
\text { waste) }\end{array}$ & $\begin{array}{l}\text { Particle size } \\
\text { distribution }\end{array}$ & $\begin{array}{l}30 \% \text { to } 40 \% \text { of the waste generated from the mining process } \\
\text { was found suitable to be used for road construction and } \\
\text { manufacture of bricks }\end{array}$ & $\begin{array}{l}\text { Asokan Pappu et } \\
\text { al.(2006) }\end{array}$ \\
\hline $\begin{array}{l}\text { Black cotton } \\
\text { soil }+ \\
\text { Copper slag }\end{array}$ & $\begin{array}{l}\text { Compaction } \\
\text { CBR }\end{array}$ & $\begin{array}{l}\text { For the combination of } 72 \% \text { of BC soil and } 28 \% \text { of copper slag } \\
\text { soaked CBR value increased from } 1.64 \% \text { to } 5.43 \% \text {. High value } \\
\text { of MDD } 1.9 \mathrm{~g} / \mathrm{cc} \text { and OMC } 18 \% \text { was obtained for } 68 \% \mathrm{BC} \text { soil } \\
\text { with } 32 \% \text { copper slag as compared to the conventional mix of } \\
\text { MDD } 1.64 \mathrm{~g} / \mathrm{cc} \text { for the same optimum moisture content. }\end{array}$ & $\begin{array}{l}\text { Tushal Baraskar } \\
\text { S K Ahirwar }\end{array}$ \\
\hline $\begin{array}{l}\text { Black cotton } \\
\text { soil }+ \\
\text { Copper slag }\end{array}$ & $\begin{array}{l}\text { Atterburg } \\
\text { limits, CBR, } \\
\text { Compaction, } \\
\text { Swelling } \\
\text { Index, Direct } \\
\text { shear, UCS, } \\
\text { Permeablity }\end{array}$ & $\begin{array}{l}\text { Copper slag - black cotton soil mix (30:70) has a low free swell } \\
\text { index of } 38 \% \text {. By utilizing this mix we can avoid the problems } \\
\text { of swelling and shrinkage of expansive soil. The coefficient of } \\
\text { permeability of copper slag was found to be } 2.8 \times 10-6 \mathrm{~m} / \text { that } \\
\text { indicates its potentiality for its use as a drainage layer in road } \\
\text { base. The coefficient of permeability of copper slag local soil } \\
\text { mix }(30: 70) \text { was found to be } 5.7 \times 10-9 \mathrm{~m} / \mathrm{s} \text {, thus proving its } \\
\text { impervious nature and thus it's suitability as a subgrade in road } \\
\text { pavement. For the same mix soaked CBR value increased } \\
\text { considerably. }\end{array}$ & $\begin{array}{l}\text { Yogendra K Tandel } \\
\text { Jignesh B Patel }\end{array}$ \\
\hline $\begin{array}{l}\text { Black cotton } \\
\text { soil }+ \\
\text { Copper slag }\end{array}$ & $\begin{array}{l}\text { Grain size } \\
\text { distribution, } \\
\text { CBR, UCS }\end{array}$ & $\begin{array}{l}30 \% \text { to } 60 \% \text { of the copper slag can be stabilized with Black } \\
\text { Cotton soil to improve the soil characteristics. It can hence be } \\
\text { recommended for construction of embankment, improvement of } \\
\text { subgrade soil condition and reclamation of land. }\end{array}$ & $\begin{array}{l}\text { Prof. Jinka } \\
\text { Chandrshekhar et } \\
\text { al. }\end{array}$ \\
\hline
\end{tabular}




\begin{tabular}{|c|c|c|c|}
\hline $\begin{array}{l}\text { Alteration } \\
\text { Agent }\end{array}$ & $\begin{array}{l}\text { Test Carried } \\
\text { out }\end{array}$ & Remarks & References \\
\hline $\begin{array}{l}\text { Soil } \\
+ \\
\text { Copper slag } \\
+ \\
\text { Cement }\end{array}$ & $\begin{array}{l}\text { Load } \\
\text { settlement } \\
\text { characteristics }\end{array}$ & $\begin{array}{l}\text { There was a remarkable improvement in the ultimate load of } \\
\text { copper slag cushion - expansive soil bed when admixed with } \\
\text { cement and lime. It was also noticed that ultimate load is } 1.7 \\
\text { times when } 4 \% \text { lime was added to copper slag and it was } \\
\text { increased three times when } 6 \% \text { lime was added to copper slag. } \\
\text { For the same percentage of admixture added, it was noticed that } \\
\text { the increase the ultimate load is more for cement when } \\
\text { compared to that lime. }\end{array}$ & C Lavanya et al. \\
\hline $\begin{array}{l}\text { Soil }+ \\
\text { Copper slag } \\
+ \text { Cement }\end{array}$ & $\begin{array}{l}\text { Atterburg } \\
\text { limits, CBR, } \\
\text { Compaction, } \\
\text { FSI }\end{array}$ & $\begin{array}{l}\text { Soil stabilization with copper slag for an optimum mix of } 30 \% \\
\text { proved to be more efficient reducing plasticity index by } 40 \% \text {. } \\
2 \% \text { of cement was added to stabilized mix resulting in decrease } \\
\text { in FSI. Higher MDD and a lower OMC were achieved for the } \\
\text { same mix. CBR value got increased, thus making it suitable to } \\
\text { use as subgrade material. }\end{array}$ & $\begin{array}{l}\text { C Lavanya } \\
\text { A Sreerama Rao } \\
\text { N Darga Kumar }\end{array}$ \\
\hline $\begin{array}{lr}\text { Flyash } & + \\
\text { Copper } & \text { slag } \\
+ \text { Lime } & \end{array}$ & $\begin{array}{l}\text { UCS,Triaxial } \\
\text { Shear, } \\
\text { Durability }\end{array}$ & $\begin{array}{l}\text { Compacted soil-flyash-copper slag mix and compacted soil-fly } \\
\text { ash-lime/cement mix have shown improved geotechnical } \\
\text { characteristics. }\end{array}$ & $\begin{array}{l}\text { Ghosh and } \\
\text { Subbarao (2007) }\end{array}$ \\
\hline $\begin{array}{l}\text { Copper slag } \\
+ \\
\text { Fly Ash }+ \\
\text { dolime }\end{array}$ & $\begin{array}{l}\text { Compaction } \\
\text { UCS } \\
\text { FEA }\end{array}$ & $\begin{array}{l}\text { Optimum Moisture Content increased constantly for various } \\
\text { copper slag and fly ash mixes, whereas MDD increased for an } \\
\text { optimum value of } 10 \% \text {. Based on UCS test results } 80 \% \text { copper } \\
\text { slag }+20 \% \text { fly ash }+15 \% \text { dolime was found to be the optimum } \\
\text { mixes. }\end{array}$ & $\begin{array}{l}\text { J.T Shahu et al } \\
\text { (December 2013) }\end{array}$ \\
\hline $\begin{array}{l}\text { Aggregate + } \\
\text { slag } \\
\text { aggregarte }\end{array}$ & UCS & $\begin{array}{l}\text { The compressive strength of the concrete with tailings } \\
\text { aggregates at } 28 \text { days was } 36.95 \mathrm{MPa} \text { which shows an } \\
\text { improvement of } 11.56 \% \text { over the concrete with conventional } \\
\text { aggregates. }\end{array}$ & $\begin{array}{lr}\text { Francis } & \text { Atta } \\
\text { Kuranchie } & \text { (August } \\
2015) & \end{array}$ \\
\hline
\end{tabular}

Table 2.2: Soil Stabilization using Ground Granulated Blast Furnace Slag and Granulated Blast Furnace Slag

\begin{tabular}{|c|c|c|c|}
\hline $\begin{array}{l}\text { Alteration } \\
\text { Agent }\end{array}$ & $\begin{array}{l}\text { Test Carried } \\
\text { out }\end{array}$ & Remarks & References \\
\hline $\begin{array}{l}\text { Soil }+ \\
\text { Lime } \\
+ \text { GGBS }\end{array}$ & UCS & $\begin{array}{l}\text { Addition of Lime content up to } 8 \% \text { to attain a } 1: 1 \text { ratio of } \\
\text { substitute with GGBS at } 23 \% \text { moisture content showed higher } \\
\text { strength even under soaked condition. UCS gained high rate of } \\
\text { strength of } 4000 \mathrm{kN} / \mathrm{m}^{2} \text { at } 56 \text { days curing, which later slowed } \\
\text { down till } 90 \text { days resulting a strength higher than } 4500 \mathrm{kN} / \mathrm{m}^{2}\end{array}$ & $\begin{array}{l}\text { G.N. Obuzor } \\
\text { J.M. Kinuthia, } \\
\text { R.B. Robinson }\end{array}$ \\
\hline $\begin{array}{l}\text { Soil } \\
\text { GBFS }\end{array}$ & $\begin{array}{l}\text { Atterburg } \\
\text { limits, } \\
\text { Compaction } \\
\text { Swelling } \\
\text { Index }\end{array}$ & $\begin{array}{l}\text { The GBFS obtained from the Iskenderun iron-steel plant were } \\
\text { incorporated into low plasticity Kolsuz clay and high-plasticity } \\
\text { bentonite clay in various rates }(5 \%, 10 \%, 20 \%, 30 \% \text {, and } 50 \%) \text {. } \\
\text { The stabilization turned out to be positive and the improvement } \\
\text { in bentonite clay is greater than that in Kolsuz clay. }\end{array}$ & $\begin{array}{lr}\text { Osman } & \text { Sivrikaya, } \\
\text { Selman } & \text { Yavascan } \\
\text { and Emre } & \text { Cecen }\end{array}$ \\
\hline $\begin{array}{l}\text { Soil } \\
\text { GGBS }\end{array}$ & $\begin{array}{l}\text { Atterburg } \\
\text { limits, } \\
\text { Compaction } \\
\text { Swelling } \\
\text { Index, CBR }\end{array}$ & $\begin{array}{l}\text { By blending with GGBS there is a substantial improvement in } \\
\text { compaction parameters while considerable improvement was } \\
\text { also seen in CBR value up to } 10 \% \text {. There was a reduction of } \\
5 \% \text { in liquid limit and Plasticity Index. }\end{array}$ & $\begin{array}{l}\text { K Uppaiah, G V } \\
\text { Prasad Raju (2013) }\end{array}$ \\
\hline $\begin{array}{l}\text { Soil }+ \\
\text { GGBS }+ \\
\text { Road Cem }\end{array}$ & $\begin{array}{l}\text { UCS } \\
\text { Free swell } \\
\text { Percentage, }\end{array}$ & $\begin{array}{l}\text { Unconfined Compressive Strength of soil increased with } 65 \% \\
\text { of OPC by GGBS. With addition of lime up to } 12 \% \text { there was a } \\
\text { further gain in UCS value. Free swell Index was inversely } \\
\text { proportional to increase in stabilizer. }\end{array}$ & $\begin{array}{l}\text { M. S. Ouf (20 } \\
13)\end{array}$ \\
\hline
\end{tabular}




\begin{tabular}{|c|c|c|c|}
\hline $\begin{array}{l}\text { Alteration } \\
\text { Agent }\end{array}$ & $\begin{array}{l}\text { Test Carried } \\
\text { out }\end{array}$ & Remarks & References \\
\hline $\begin{array}{l}\text { Soil }+ \\
\text { GBFS }+ \\
\text { Waste } \\
\text { rubber tyres }\end{array}$ & $\begin{array}{l}\text { Compaction } \\
\text { CBR }\end{array}$ & $\begin{array}{l}\text { The influence of Granulated blast furnace slag and waste } \\
\text { rubber tyre chips is marginal on MDD and high for OMC. The } \\
\text { OMC is found to increase by } 1.9 \text { times with GBFS and } 2.3 \\
\text { times with WRT as compared with unmodified aggregate. An } \\
\text { optimum filler content of } 5 \% \text { with GBFS and } 2 \% \text { with WRT is } \\
\text { recommended for best results. } 3 \text {. It is concluded that the } \\
\text { efficacy of GBFS is higher to that of WRT. At optimum } \\
\text { conditions CBR increase with GGBS from } 40.78 \% \text { and } 46.60 \% \\
\text { at } 20 \% \text { GBFS content is very high to that with WRT i.e from } \\
4.71 \% \text { to } 7.7 \% \text { at } 2 \% .4 \text {. }\end{array}$ & $\begin{array}{l}\text { K.V.Subrahmanyam } \\
\text { V.K.Chakravarthi } \\
\text { U.Arun Kumar }\end{array}$ \\
\hline $\begin{array}{l}\text { Soil + Lime } \\
+ \text { GBFS }\end{array}$ & $\begin{array}{l}\text { Grain size } \\
\text { distribution } \\
\text { Compaction } \\
\text { CBR, UCS }\end{array}$ & $\begin{array}{l}\text { There was a pronounced increase in the soaked CBR When } \\
\text { lime-stabilized GBS cushion was placed over the expansive } \\
\text { soil. Lime content of } 10 \% \text { resulted in to increase in shear } \\
\text { strength corresponding to unit normal stress. }\end{array}$ & $\begin{array}{l}\text { G Sridevi } \\
\text { Shreerama } \quad \text { Rao } \\
(2011)\end{array}$ \\
\hline $\begin{array}{l}\text { Soil } \\
\text { GGBS }\end{array}$ & $\begin{array}{l}\text { Atterburg } \\
\text { limits, CBR } \\
\text { UCS }\end{array}$ & $\begin{array}{l}\text { With the addition of } 15 \% \text { of GGGBS there was } 37 \% \text { increment } \\
\text { in CBR and } 15 \% \text { increment in UCS value. There was also } \\
\text { considerable decrease in Liquid limit and Plasticity Index. }\end{array}$ & $\begin{array}{l}\text { D Neeraja } \\
\text { A.V Narashimha } \\
\text { Rao }\end{array}$ \\
\hline $\begin{array}{l}\text { Soil } \\
\text { GGBS }\end{array}$ & CBR, UCS & $\begin{array}{l}25 \% \text { GGBS has shown higher UCS values compared to other } \\
\text { Percentage and at } 28 \text { days it has shown maximum values than } \\
\text { other curing periods. A higher value of CBR i.e, } 35 \% \text { was } \\
\text { obtained for } 25 \% \text { GGBS at } 28 \text { days curing period. Hence } \\
\text { Redmud stabilized with GGBS can be used as subbase, base } \\
\text { course and also subgrade material for road construction. }\end{array}$ & $\begin{array}{l}\text { CH.V.Hanumanth } \\
\text { et.al (August 2011) }\end{array}$ \\
\hline $\begin{array}{l}\text { Soil } \\
\text { GBFS }\end{array}$ & $\begin{array}{l}\text { Compaction } \\
\text { CBR }\end{array}$ & $\begin{array}{l}\text { Addition of GGBS to soil increased the maximum dry density } \\
\text { up to } 10 \% \text {. CBR increased with an increase in GGBS } \\
\text { percentage up to } 10 \% \text { GGBS content, and then started to } \\
\text { decrease. Partial substitution of lime by GGBS could } \\
\text { significantly reduce swelling and heave in the presence of } \\
\text { sulphates. }\end{array}$ & $\begin{array}{lr}\text { Mohamad } & \text { Nidam } \\
\text { Rahmat1 } & \text { and } \\
\text { Norsalisma } & \text { Ismail }\end{array}$ \\
\hline $\begin{array}{l}\text { Soil }+ \\
\text { GBFS + Fly } \\
\text { ash }\end{array}$ & $\begin{array}{l}\text { Compaction } \\
\text { CBR }\end{array}$ & $\begin{array}{l}\text { Fly ash and GBS when mixed with soft soil primly effected the } \\
\text { reduction of clay content and frictional resistance. This resulted } \\
\text { in an increased OMC and MDD value. 3.3\% of fly ash and } 6 \% \\
\text { of GBS were the optimum percentage since CBR test reached } \\
\text { the optimum value for both unsoaked and soaked condition. }\end{array}$ & $\begin{array}{l}\text { Laxmikant Yadu } \\
\text { Dr. R.K. Tripathi } \\
(2001)\end{array}$ \\
\hline $\begin{array}{l}\text { Soil } \\
\text { GBFS } \\
\text { Lime }\end{array}$ & $\begin{array}{l}\text { Free swell } \\
\text { Undrained } \\
\text { Shear strength }\end{array}$ & $\begin{array}{l}\text { It is found that when } 20 \% \text { slag \& } 4 \% \text { lime ( } 5: 1 \text { slag to } \\
\text { lime ratio) is added to soil, undrained shear strength (Su) } \\
\text { increased phenomenally almost by } 16 \text { times and with } 40 \% \text { slag } \\
\& 4 \% \text { lime ( } 10: 1 \text { slag to lime ratio) Su increased by } 18 \text { times. } \\
\text { It is also observed that the free swell of Black cotton soil which } \\
\text { was reduced with } 40 \% \text { slag \& } 2 \% \text { lime along with BCS. Thus, } \\
\text { we could achieve volume stability also. }\end{array}$ & $\begin{array}{l}\text { K.V Manjunath } \\
\text { L Govindaraju } \\
\text { P.V Shivapullaih }\end{array}$ \\
\hline $\begin{array}{l}\text { Soil } \\
\text { Cement } \\
\text { Slag }\end{array}$ & $\begin{array}{l}\text { Atterburg } \\
\text { limits, UCS, } \\
\text { Free swell, } \\
\text { Swell } \\
\text { pressure, } \\
\text { Compaction } \\
\end{array}$ & $\begin{array}{l}\text { Soil treated with cement slag resulted in decrease of Liquid } \\
\text { limit and Plasticity Index from } 67.3 \% \text { to } 50 \% \text { and } 32 \% \text { to } 25 \% \\
\text { respectively. Free swell also decreased from } 91 \% \text { to } 85 \% \text {. } \\
\text { Unconfined compressive strength was increased from } 57.6 \text { to } \\
77 \mathrm{KN} / \mathrm{m}^{3} \text {. }\end{array}$ & Y. Keerthi, et al. \\
\hline $\begin{array}{ll}\text { Soil } \quad+ \\
\text { GBFS } \quad+ \\
\text { GBFS- } \\
\text { Cement }\end{array}$ & $\begin{array}{l}\text { Atterburg } \\
\text { limits, Swell } \\
\text { Index CBR }\end{array}$ & $\begin{array}{l}\text { Soil stabilization with GBFSC and GBFC decreased the swell } \\
\text { index percentage. These additives also contributed in the } \\
\text { alteration of grain size distribution of the soil sample. Swell } \\
\text { Inxed value of } 6 \% \text { also satisfied the Irrigation water standard. } \\
\text { The addition of } 15 \% \text { GBFSC and } 20 \% \text { GBFS to soil reduced } \\
\text { the swell percent from } 29.4 \text { to } 10.9 \% \text { and } 3.1 \% \text {, respectively. }\end{array}$ & $\begin{array}{l}\text { Erdal Cokca } \\
\text { Veysel Yazici } \\
\text { Vehbi Ozaydin }\end{array}$ \\
\hline
\end{tabular}




\begin{tabular}{|l|l|l|l|}
\hline $\begin{array}{l}\text { Alteration } \\
\text { Agent }\end{array}$ & $\begin{array}{l}\text { Test Carried } \\
\text { out }\end{array}$ & Remarks & References \\
\hline $\begin{array}{l}\text { Soil } \\
\text { GBFS }\end{array}$ & $\begin{array}{l}\text { Compaction } \\
\text { CBR }\end{array}$ & $\begin{array}{l}\text { Addition of GGBS to soil increased the maximum dry density } \\
\text { up to 10\% GGBS addition, above which the MDD decreased. } \\
\text { CBR increased with an increase in GGBS percentage up to } \\
10 \% \text { GGBS content, and then started to decrease. Partial } \\
\text { substitution of lime by GGBS could significantly reduce } \\
\text { swelling and heave in the presence of sulphates. }\end{array}$ & $\begin{array}{c}\text { Nidam } \\
\text { and }\end{array}$ \\
\hline
\end{tabular}

\section{CONCLUSION}

- $\quad$ The waste material obtained from iron ore mining was used as an aggregate in road construction. Particle size distribution test result indicated that $50-60 \%$ by volume of mine waste can be used as coarse aggregate and 10$15 \%$ by volume can be used as fine aggregate.

- $\quad$ Soaked CBR value increased from $1.64 \%$ to $5.43 \%$ for the combination of $72 \%$ of $\mathrm{BC}$ soil and $28 \%$ of copper slag.

- $\quad$ Copper slag of $80 \%, 20 \%$ of fly ash was found to be the optimum mix based on the Unconfined Compression Test.

- $\quad$ By blending soil with GGBS CBR strength increased up to $10 \%$. There was also reduction of Liquid limit up to $5 \%$.

- $\quad$ The Maximum Dry Density and CBR value increased considerably with the addition of GGBS up to $10 \%$.

- $\quad$ The Unconfined Compression Test, Split Tensile Test has increased at 28 days curing up to the addition of $25 \%$ of GGBS.

\section{REFERENCES}

[1] Mohan Yellishetty, Vanda Karpe E.H. Reddy K.N. Subhash , P.G. Ranjith (2008) "Reuse of iron ore mineral wastes in civil engineering constructions: A case study" et al. / Resources, Conservation and Recycling 52 1283-1289

[2] Asokan Pappu, Mohit Sexana, Shyam R. Asolekar (2007) "Soild Waste Generation in India and their recycling potential in building materials", Building and Environment 42 -2311-2320

[3] Sathyanarayanan Rajendran, John A. Gambatese, M.ASCE (2007) "Soild Waste Generation in Asphalt and Reinforced Concrete Roadway Life Cycles", Journal of Infrastructure system. 13:88-96

[4] Tushal Baraskar, S K Ahirwar (2014) "Study on California Bearing Ratio of Black Cootton Soil Use Waste Copper Slag", International Journal of Structural and Civil Engineering Research, Volume 3 No 4, November 2014.

[5] Yogendra K Tandel Jignesh B Patel (2009), "Review of Utilisation of Copper Slag in Highway Construction", Australian Geomechanics Vol 44 No 3 September 2009

[6] Lavanya C et al. (2013), "Influence of Admixtures on load - settlement behaviour of Copper slag Cushioned Expansive Soil Bed", Proceedings of
Indian Geotechnical Conference December 22-24, 2013, Roorkee.

[7] Kayal Rajakumaran, (2015) “An Experimental Analysis on Stabilization of Expansive Soil with Steel Slag and Fly Ash", International Journal of Advances in Engineering \& Technology, Vol. 7, Issue 6, pp. 1745-1752 Jan., 2015

[8] Prof. Jinka Chandrshekhar (2015), "A Review on Utilization of Waste Material "Copper Slag" in Geotechnical Applications", International Journal for Innovative Research in Science \& Technology| Volume 1 | Issue 12 | May 2015.

[9] Ghosh and Subbarao (2007), "Strength Charactreictics of Fly Ash Modified with Lime and Gypsum”, Journal of Geotechnical and GeoEnvironmental Engineering, vol 133, Issue 7, page:757-766, July 2007.

[10] C.Lavanya, A. Sreerama Rao (2013), N. Darga Kumar "Study on Coefficient of Permeability of Copper slag when admixed with Lime and Cement" OSR Journal of Mechanical and Civil Engineering (IOSR-JMCE) e-ISSN: 2278-1684,p-ISSN: 2320-334X, Volume 7, Issue 6 (Jul. - Aug. 2013), PP 19-25.

[11] Francis Atta Kuranchie (August 2015), “ Characterisation and Applications of Iron ore Tailings in Buildings and Construction Projects", $\mathrm{PhD}$ thesis

[12] G.N. Obuzor, J.M. Kinuthia, R.B. Robinson (2011) "Utilisation of lime activated GGBS to reduce the deleterious effect of flooding on stabilised road structural materials: A laboratory simulation" Engineering Geology 122 334-338

[13] K Uppaiah, G V Prasad Raju (2013) "Relative performance of VPW \& GGBS in Improving Expansive Soil Subgrade", Proceedings of Indian Geotechnical Conference December 22-24,2013, Roorkee

[14] M.S Ouf (2012), "Effect of Using Pozzolanic materials on the Properties of Egyptian Soils" Life Science Journal, 2012;9(1).

[15] G. Sridevi, A Sreerama Rao (2011), "Utilisation of GBS in Road Sub-Base" Proceedings of Indian Geotechnical Conference December 15-17,2011, Kochi (Paper No. H-076).

[16] K.V.Subrahmanyam 1 , V.K.Chakravarthi 2* , U.Arun Kumar, "Performance evaluation of stabilized GSB mix- A quantitative study" American Journal of Engineering Research (AJER) e-ISSN : 2320847 pISSN : 2320-0936 Volume-3, Issue-9, pp-241-250

[17] CH.V.Hanumanth Rao, Ganapati Naidu. P, P.V.V .Satyanayarana (2012), "Application of GGBS 
stabilized Redmud in Road Construction" IOSR

Journal of Engineering (IOSRJEN) ISSN: 2250-3021

Volume 2, Issue 8 (August 2012), PP 14-20

[18] D.Neeraja, Prof .A.V.Narasimha Rao (2010), "Use of Certain admixtures in the Construction of Pavement on Expansive Clayey Subgrades" International Journal of Engineering Science and Technology Vol. 2(11), 2010, 6108-6114

[19] Ece Celik, Zalihe Nalbantoglu (2013) "Effects of ground granulated blastfurnace slag (GGBS) on the swelling properties of lime-stabilized sulfate-bearing soils" Engineering Geology 163 (2013) 20-25.

[20] Mohammad et al (2001), "Stabilisation of Clay Subgrade Soils Using Ground Granulated Blast furnace slag", PhD thesis, November 2001.

[21] Zhengfu Bian, Xiexing Miao, Shaggang Lei, Shen-en, Wenfeng, Sue Struthurs (2012), "The Challenges of reusing Mining and Mineral Processing Wastes", Journal of Sciencemag, Vol 337, August 2012 Pp702-703.

[22] Laxmikanth Yadav, Tripathi RK (2013), "Stabilization of Soft soil using GGBS and Fly Ash", vol 2, Issue 2, Febrauary 2013

[23] K.V Manjunath, L Govindaraju (2011), "Blast Furnace Slag for Bulk GeoTechnical Applications", Indian GeoTechnical Conference.

[24] Y. Keerthi, et al. (2013), "Stabilization of Clayey Soil using Cement Kiln Waste", International Journal of Advanced Structures and GeoTechnical Engineering, Vol 02, No 02,, April 2013.

[25] CH.V.Hanumanth Rao (2013), “A Study on CBR Behaviour on Waste Plastic on Stabilized Red Mud and Fly Ash", International Journal of Research Engineering and Technology, vol 3 pp 20-26, 2013.

[26] A.G.N Kitula (2006), "The environmental and socioeconomic impacts of mining on local livelihoods in Tanzania: A case study of Geita District", Journal of Cleaner Production 14- 405e414.

[27] Liu Haibin, Liu Zhenling (2010), "Recycling utilization patterns of coal mining waste in China" Resources, Conservation and Recycling 54 (2010) 1331-1340.

\section{BIOGRAPHIES}

Prof Shravan A.Kanalli, (Shravan A.Kanalli is an MTech graduate in Transportation Engineering and Management from BMS College of Engineering, Bengaluru. $\mathrm{He}$ is currently working as Assistant Professor in SDM College of Engineering and Technology, Dharwad, Karnataka, India since April 2012)

Dr Sureka Naagesh, is an $\mathrm{PhD}$ holder from Bangalore University. She is currently working as Professor in the department of Civil Engineering, BMS college of engineering, Bengaluru

Dr Ganesh K, is an $\mathrm{PhD}$ holder from Visvesvaraya Technological University. $\mathrm{He}$ is currently working as Assistant Professor in the department of Civil Engineering, BMS college of engineering, Bengaluru 